\title{
Tudjuk, hol a határ? - A Sürgősségi Betegellátó Osztályt akut alkoholintoxikáció miatt felkereső betegek ellátásának elemzése
}

\author{
Bánfai-Csonka Henrietta ${ }^{1,2,4}$. Bánfai Bálint dr. ${ }^{2}$ \\ Boncz Imre dr. ${ }^{3}$ - Betlehem József $\mathrm{dr} .{ }^{2}$
}

\begin{abstract}
${ }^{1}$ Pécsi Tudományegyetem, Egészségtudományi Kar, Egészségtudományi Doktori Iskola, Pécs ${ }^{2}$ Pécsi Tudományegyetem, Egészségtudományi Kar, Sürgősségi Ellátási és Egészségpedagógiai Intézet, Pécs ${ }^{3}$ Pécsi Tudományegyetem, Egészségtudományi Kar, Egészségbiztosítási Intézet, Pécs ${ }^{4}$ Pécsi Tudományegyetem, Klinikai Központ, Sürgősségi Orvostani Tanszék, Pécs
\end{abstract}

Bevezetés: A WHO adatai szerint évente több mint 2 millió ember hal meg alkoholabúzus miatt. Az alkoholt fogyasztók egy része a sürgősségi betegellátó rendszerben jelenik meg. Van, aki csupán józanodás céljából, van, aki az alkoholfogyasztással összefüggésbe hozható baleseti sérülés miatt, és van, aki az ehhez köthető belgyógyászati betegségei következtében.

Célkitüzés: Kutatásunk céljául tűztük ki, hogy feltárjuk, hány alkoholbefolyásoltság alatt álló beteg kerül be a kórházi sürgősségi ellátórendszerbe, illetve a finanszírozás szempontjából mekkora terhet rónak az ellátóosztályra.

Módszer: Kutatásunkat a Pécsi Tudományegyetem Klinikai Központja Sürgősségi Betegellátó Tanszékének Sürgősségi Betegellátó Osztályán végeztük, a 2016. január 1. és december 31. közötti időszakban. Mintánkat a Sürgősségi Betegellátó Osztályon megjelent, alkoholbefolyásoltság alatt álló, felvételre jelentkező betegek alkották $(\mathrm{n}=1326)$. $\mathrm{Az}$ adatokat dokumentumelemzés keretén belül értük el. Az adatok elemzését SPSS 22.0 statisztikai szoftverrel végeztük.

Eredmények: A bekerülő betegek 78\%-a férfi volt. A minta átlagéletkora $50 \pm 14,518$ év volt. A lakhellyel rendelkezők a minta 71,1\%-át, míg a hajléktalan betegek a 28,9\%-át képezték. A triage-skála szerint 608 beteg a T5-ös kategóriába került, mivel csak detoxikálásra volt szükségük. A tudatszint tekintetében a betegek 93,7\%-a a Glasgow Kóma Skála (GCS) szerinti 14 vagy 15 pontot kapott. A betegek 14,6\%-a nem várta meg az orvosi vizsgálatot. A járó- és fekvőbeteg-ellátás keretén belül is, ezen betegek ellátása nyereségesnek mondható a vizsgált változók tekintetében. Következtetés: A sérülések diagnosztikája és ellátása a hazai irányelveknek megfelelően történik. A várttal ellentétben ezen betegek ellátása nyereséges az osztály számára, bár a kiadások szempontjából csak a fix költségek kerültek összegzésre.

Orv Hetil. 2019; 160(43): 1698-1705.

Kulcsszavak: sürgősségi betegellátás, alkoholintoxikáció, finanszírozás

\section{Do we know the limits? - Overview of cases related to acut alcohol intoxication in emergency department}

Introduction: According to WHO data, more than 2 million people die because of alcohol consumption during one year. One part of these people are displayed in the emergency departments. There are those who are just about to be detoxicated, those who suffered alcohol-related accidents or alcohol-related internal illness.

Aim: To find out how many alcohol-influencing patients are being in the emergency care system and how much of the financing are used for these patients.

Method: Our research was conducted at the Department of Emergency Medicine, Clinical Centre, University of Pécs. The research period was between January 1 and December 31, 2016. Our sample was made up of patients who were exposed due to alcohol in the emergency room $(\mathrm{n}=1326)$. We made document analysis. We analysed data using statistical software SPSS 22.0 . 
Results: $78 \%$ of the patients were male. The mean age of the sample was $49.78 \pm 14.215$ years. $71.1 \%$ of patients had a home, but $28.9 \%$ were homeless. According to the Triage scale, 608 patients were in category T5 because they needed only detoxification. In terms of the level of consciousness, $93.7 \%$ of patients had 14 or 15 points according to the Glasgow Coma Scale. 14.6\% of patients did not expect a medical examination. Within the framework of incoming and outpatient care, the provision of these patients is profitable.

Conclusion: The diagnosis and care of the injuries is done in accordance with the domestic guidelines. Contrary to expectations, the care of these patients is profitable for the emergency department, although only fixed costs were included.

Keywords: emergency care, alcohol intoxication, financing

Bánfai-Csonka H, Bánfai B, Boncz I, Betlehem J. [Do we know the limits? - Overview of cases related to acut alcohol intoxication in emergency department]. Orv Hetil. 2019; 160(43): 1698-1705.

(Beérkezett: 2019. április 8.; elfogadva: 2019. május 14.)

\begin{abstract}
Rövidítések
ANOVA $=($ analysis of variance $)$ varianciaanalízis; $\mathrm{BNO}=\mathrm{Be}-$ tegségek Nemzetközi Osztályozása; CT = (computed tomography) számítógépes tomográfia; EKG = elektrokardiográfia; ELEF = Egészségügyi Lakossági Egészségfelmérés; GCS = (Glasgow Coma Scale) Glasgow Kóma Skála; OENO = Orvosi Eljárások Nemzetközi Osztályozása; OMSZ = Országos Mentôszolgálat; PTE = Pécsi Tudományegyetem; $\mathrm{SBO}=$ Sürgősségi Betegellátó Osztály; $\mathrm{WHO}=$ (World Health Organization $)$ Egészségügyi Világszervezet
\end{abstract}

Napjainkban az alkohol és a dohányáruk olyan legálisan hozzáférhető élvezeti szerek, amelyek hozzászokást okozhatnak. Ezek mind az egyén, mind a társadalom számára komoly problémát jelentenek. Az alkoholfogyasztás nem illegális, és alkalomszerüen a társadalom nagyobb hányada fogyaszt alkoholt, így nehéz kiszürni, hogy valakinél mikor éri el a kóros, függőségi szintet. 2018-ban közölt WHO-adatok alapján 2016-ban több mint 3 millió ember halálához vezetett a túlzott alkoholfogyasztás [1], míg ez a szám 2012-ben csak 2 millió volt [2]. A magzatialkohol-szindróma és az alkoholfogyasztás rendellenességei 100\%-ban függnek az alkoholbeviteltől. A magzati halálozási ok 5,9\%-a összefüggésbe hozható volt az alkoholfogyasztással 2012-ben [3].

A világon 237 millió férfit és 46 millió nőt érintenek az alkoholfogyasztási zavarok. Ez az arány Európában ( $14,8 \%$ és $3,5 \%)$ és Amerikában ( $11,5 \%$ és $5,1 \%$ ) a legnagyobb a népességre vonatkoztatva [1].

$\mathrm{Az}$ alkoholbetegség a háziorvosok szerint nagyobb mértékben érinti az 50 év feletti, munka nélküli, inaktív személyeket. Ezzel szemben a betegkérdőívek azt mutatják, hogy a fiatal, munkával rendelkezők körében több az ilyen beteg [4]. A 2014 és 2015 között felvett Egészségügyi Lakossági Egészségfelmérés (ELEF) adatai alapján hazánkban a nagyivók közé a 65 év felettiek tartoznak a legnagyobb arányban (14\%), az összes férfi 9,9\%-a. Hazánkban a lakosság 5,4\%-a tartozik a nagyivók közé, ez a 2009-es adatokhoz képest emelkedett $(4,6 \%)$ [5].
A nagyivók körét azonban bóvítette az az interneten elterjedt kihívás, amely fiatal személyeket célzott meg, hogy minél gyorsabban rúgjanak be, és erre buzdítsák társaikat is [6]. Egy német kutatás az idős emberek körében fogyasztott pszichotrop szerek és alkohol gyakoriságát vizsgálta. A kutatás kimutatta, hogy a megkérdezettek 18,4\%-a fogyaszt alkoholt napi szinten, 2,8\% pedig rendszeresen használ pszichoszomatikus szert is az alkohol mellé [7]. Ezek a kutatások is bizonyítják, hogy az alkoholprobléma a társadalom minden korosztályát érinti. Az alkoholt fogyasztó betegek - ideértve az intoxikált betegeket is - egy része a sürgősségi betegellátó rendszerben jelenik meg. A sürgősségi osztályok az egészségügyi ellátórendszer legleterheltebb részei [8], így felmerül a kérdés, hogy ezeket a betegeket biztosan a sürgősségi ellátóosztályokon kellene-e detoxikálni. A betegek sokszor nincsenek tisztában a sürgősségi betegellátó osztályok szerepével, így indokolatlanul keresik fel azokat, ezzel is terhelve a rendszert. Az alkoholintoxikált betegek nagy számban kerülnek az ellátórendszerbe [911]. Ezen betegek esetében az alkohol- és/vagy droghatás miatt kialakult agresszivitás is gondot jelent [12]. Az alkoholintoxikált betegek az egészségügyi ellátás kiadásainak 1,3-3,3\%-át teszik ki, míg az alkoholfogyasztással összefüggő betegségek, sérülések a kiadások további 1\%át képezik a fejlett és fejlődő országokban [13]. Kutatások kimutatták, hogy az alkoholintoxikált betegek nagy része pszichés probléma vagy sérülés miatt került a sürgősségi osztályra $[9,14]$, a sérülésekkel összefüggésben több osztályos felvételre is sor kerül [11]. Egy finn kutatás kimutatta, hogy a biciklibalesetek közül azon esetekben, amikor a sérült fogyasztott alkoholt, súlyosabb sérülések történtek, valamint az esetek 64\%-ában a sérülést elszenvedett biciklizők nem viseltek védősisakot [14].

Kutatásunk céljául tűztük ki, hogy feltárjuk, hány alkoholbefolyásoltság alatt álló beteg került be a kórházi sürgösségi ellátórendszerbe a 2016-os évben, illetve a finanszírozás szempontjából mekkora terhet róttak az ellátóosztályra. Továbbá szerettük volna felmérni, hogy 
milyen arányban fordulnak elő kizárólag az alkohol hatása miatt bekerülő betegek (az alkoholbefolyásoltság az egyedüli probléma), és mekkora az alkoholfogyasztással összefüggésbe hozható sérülések, betegségek miatt megjelenők száma (sérülés, betegség az elsődlegesen megoldandó feladat, az alkoholbefolyásoltság másodlagosnak tekinthetö).

\section{Módszer}

Kutatásunk retrospektív, kvantitatív vizsgálat volt. Kutatásunkat Pécsen, a Pécsi Tudományegyetem Klinikai Központjának Sürgősségi Betegellátó Osztályán végeztük el. A vizsgálat 1 éves betegforgalmat ölelt fel, 2016. január 1. és december 31. között. Az adatokat 2017. június-október között kérdeztük le az osztályon használt egészségügyi informatika rendszerből (e-MED Solution).

Célcsoportunk a Sürgősségi Betegellátó Osztályon megjelent, alkoholbefolyásoltság alatt álló, ellátás miatt az Országos Mentőszolgálat (OMSZ) által szállított vagy önként, hozzátartozóval, egyéb kísérővel felvételre jelentkező betegek. Az adott időszakra, helyre és célcsoportra vonatkoztatva teljes körü mintavétel történt. A vizsgálatba azon betegeket választottuk be, akik a vizsgált sürgősségi osztályon alkoholbefolyásoltság miatt vagy alkoholfogyasztáshoz kapcsolódó sérülés miatt jelentek meg. Az alkoholfogyasztás kis mérték esetén is kimutatható volt, mivel véralkoholszint-mérés történik minden betegnél, akinél felmerül az alkoholfogyasztás (auto-, heteroanamnézis, viselkedés alapján). Vizsgálatunkba beválasztásra kerültek a társbetegségekkel rendelkező betegek is. Vizsgálatunkból kizárásra kerültek azok a személyek, akiknél a vizsgálni kívánt tényezők hiányosan kerültek dokumentálásra, külföldi állampolgárságú betegek voltak, vagy a beteg véralkoholszintje $20 \mathrm{mg} / \mathrm{ml}$ alatt volt. Az elemszám 1372 volt, azonban a kizárási kritériumok miatt 1326 eset alkotta a végleges mintánkat.

1. táblázat |Az elfogyasztott alkoholmennyiség és -befolyásoltság szintjei

\begin{tabular}{ll}
\hline A véralkoholszint értéke & Az alkoholbefolyásoltság mértéke \\
\hline$<0,2 \%{ }_{0} \leq 20 \mathrm{mg} \%$ & $\begin{array}{l}\text { Az alkoholfogyasztás nem } \\
\text { bizonyítható }\end{array}$ \\
$0,21-0,50 \%{ }_{0}=21-50 \mathrm{mg} \%$ & $\begin{array}{l}\text { Ivott, de alkoholosan nem volt } \\
\text { befolyásolt }\end{array}$ \\
$0,51-0,80 \%{ }_{0}=51-80 \mathrm{mg} \%$ & Igen enyhe befolyásoltság \\
$0,81-1,50 \%{ }_{0}=80-150 \mathrm{mg} \%$ & Enyhe befolyásoltság \\
$1,51-2,50 \%=151-250 \mathrm{mg} \%$ & Közepes befolyásoltság \\
$2,51-3,5 \%=251-350 \mathrm{mg} \%$ & Súlyos befolyásoltság \\
$>3,50 \% 0 \geq 350 \mathrm{mg} \%$ & Igen súlyos fokú befolyásoltság \\
\hline
\end{tabular}

Forrás: Országos Igazságügyi Orvostani Intézet 13. módszertani levele az alkoholos állapot és alkoholos befolyásoltság orvosszakértői vizsgálatáról és véleményezéséről [15].
Az adatokat dokumentumelemzés céljából a Klinikai Központ egészségügyi számítógépes rendszeréből (e-Med Solution), a szükséges kutatási engedély (PTE/29765/2017) megszerzése után kérdeztük le.

A betegek adatainak azonosítása érdekében a betegek számjegyazonosítót kaptak, így biztosítva az anonimitást.

A véralkoholszint meghatározása laborvizsgálattal történt, a beteg beérkezését követően, a triage-vizsgálat során levett vérből. A befolyásoltság szintjeit, mely szerint a beosztást végeztük, a 1. táblázat mutatja be. Az idevonatkozó adatokhoz az „Országos Igazságügyi Orvostani Intézet 13. módszertani levele az alkoholos állapot és alkoholos befolyásoltság orvosszakértői vizsgálatáról és véleményezéséről” [15] szolgált alapul.

Az adatbázis elkészítéséhez és a statisztikai számítások elvégzéséhez SPSS 22.0 statisztikai szoftvert (IBM Corporation, Armonk, NY, Amerikai Egyesült Államok) használtunk. A mintát leíró statisztikai mutatókkal (abszolút és relatív gyakoriság, átlag, szórás, minimum, maximum) jellemeztük. Az összefüggések vizsgálatára matematikai statisztikai eljárásokat alkalmaztunk (chinégyzet-próba, ANOVA). Az adatokat 95\%-os konfidenciaintervallum mellett, $\mathrm{p}<0,05$ esetén tekintettük szignifikánsnak.

\section{Eredmények}

\section{A szociodemográfiai adatok bemutatása}

A vizsgálat helyszínéül szolgáló Sürgősségi Betegellátó Osztályon 2016. január 1. és december 31. között 40659 beteg jelentkezett felvételre. Ebból mintánkat összesen 1326 eset $(3,3 \%)$ alkotta.

Ebből 292 (22\%) esetben nő volt a beteg, míg 1034 (78\%) esetben férfi. Az átlagéletkor $50 \pm 14,518$ év volt. A legfiatalabb beteg 19 éves, míg a legidősebb 88 éves volt. A beválasztott esetek közül a betegek 942 esetben (71,1\%) rendelkeztek lakcímmel, míg 383 esetben $(28,9 \%)$ nem. Egy esetben a beteg szociális otthonból érkezett, ez azonban összevonásra került az állandó lakhellyel rendelkezőkkel. Arányaiban nézve a nők és a férfiak esetében is több alkalommal jelentek meg lakcímmel rendelkezők (nők: 75,3\%, férfiak: 69,8\%), mint lakcím nélküliek. A férfiak körében a lakcím nélküli esetek gyakrabban fordultak elő, mint a nők körében (nők: 24,7\%, férfiak: $30,2 \%)$, az eredmény azonban nem szignifikáns $(\mathrm{p}=0,273)$.

A betegek bejutása több módon történhetett a Sürgősségi Betegellátó Osztályra. A betegek többsége az OMSZ által került beszállításra, ami 1315 beteget jelentett (a minta 99,1\%-a). A vizsgálatból láthatjuk, hogy csak 11 beteg érkezett egyedül vagy kísérővel $(0,9 \%)$. A betegek elsődleges vizsgálatának eredményeit a 2. táblázat mutatja be. A vizsgált esetekben a betegek 58 esetben $(4,4 \%)$ már ezen vizsgálat előtt elhagyták az osztályt. 
A betegek bejutásának jellemzői, illetve a triage-vizsgálat eredményei

\begin{tabular}{llc}
\hline A bejutás módja & OMSZ & $1315(99,1 \%)$ \\
& Kíséróvel & $10(0,8 \%)$ \\
& Egyedül & $1(0,1 \%)$ \\
\hline A bekerülés indoka & Kizárólag ittasság & $779(58,8 \%)$ \\
& Sérülés & $468(34,8 \%)$ \\
& Egyéb & $85(6,4 \%)$ \\
\hline Triage-kategória & 1 & $8(0,6 \%)$ \\
& 2 & $64(4,8 \%)$ \\
& 3 & $535(40,3 \%)$ \\
& 4 & $111(8,4 \%)$ \\
& 5 & $608(45,9 \%)$ \\
\hline GCS & $<9$ & $15(1,1 \%)$ \\
& $9-13$ & $69(5,2 \%)$ \\
& $14-15$ & $1242(93,7 \%)$ \\
\hline
\end{tabular}

GCS = Glasgow Kóma Skála; OMSZ = Országos Mentőszolgálat

A kórházba kerülés indoka az esetek több mint felében $(58,8 \%)$ kizárólag az ittasság volt, ugyanakkor 468 esetben a betegek az ittassághoz társuló valamilyen sérülés miatt keresték fel az osztályt. Ezek között voltak mechanikai (például végtagsérülés, fejsérülés) és termikus (fagyás) sérülések is. 85 esetben egyéb, belgyógyászati jellegü panaszt említettek a páciensek. Ezek főként a szédülés, hányinger, hányás, hasi fájdalom voltak.

\section{A véralkoholszinttel összefüggésben vizsgált mutatók}

A betegek tudati szintjének felmérésére a Glasgow Coma Skálát (GCS) használtuk. A betegek GCS-értéke és az alkoholos befolyásoltságot mutató csoportok között nem volt szignifikáns összefüggés ( $\mathrm{p}=0,396)$.

A 3. táblázat a betegek ellátásával kapcsolatos diagnosztikai, terápiás adatokat mutatja be. Az elemszám eltérést mutat $(\mathrm{n}=1272)$, mivel ezen vizsgálatokban a már a triage-vizsgálat előtt távozott betegek nem vettek részt.

Vizsgálatunk elején feltételeztük, hogy összefüggés lesz kimutatható a bekerülés oka - miszerint a betegnek az alkoholfogyasztással összefüggésbe hozható sérülése van, vagy csak ittas - és az érkezési véralkoholszint között. A két változó közti összefüggést vizsgálva az eredmény nem szignifikáns $(\mathrm{p}=0,115)$, tehát összefüggés nem volt kimutatható. A bekerült személyek átlagos véralkoholszintje $285,37 \pm 87,854 \mathrm{mg} / \mathrm{dl}$ volt. A legalacsonyabb mért alkoholszint $26 \mathrm{mg} / \mathrm{dl}$, míg a legmagasabb $566 \mathrm{mg} / \mathrm{dl}$ volt.

A vizsgálat során kimutatható volt, hogy mindkét nem esetén a „súlyos” kategóriában (a kategóriameghatározást ld. az 1. táblázatban) képviseltették magukat a legtöbben a bekerült személyek közül (nők: 127 fö; 44,1\%,
3. táblázat |A betegek ellátásával kapcsolatos adatok $(\mathrm{n}=1272)$

\begin{tabular}{llc}
\hline $\begin{array}{l}\text { Alkoholszint- } \\
\text { kategóriák }\end{array}$ & $\begin{array}{l}\text { Ivott, de nem befolyásolta } \\
(21-50 \mathrm{mg} / \mathrm{dl})\end{array}$ & $6(0,5 \%)$ \\
& Igen enyhe $(51-80 \mathrm{mg} / \mathrm{dl})$ & $13(1 \%)$ \\
& Enyhe $(81-150 \mathrm{mg} / \mathrm{dl})$ & $76(6,0 \%)$ \\
& Közepes $(151-250 \mathrm{mg} / \mathrm{dl})$ & $328(25,8 \%)$ \\
& Súlyos $(251-350 \mathrm{mg} / \mathrm{dl})$ & $529(41,6 \%)$ \\
& Igen súlyos $(>350 \mathrm{mg} / \mathrm{dl})$ & $320(25,2 \%)$ \\
\hline Diagnosztika & Labor & $1272(95,9 \%)$ \\
& CT & $437(33 \%)$ \\
& RTG & $91(6,9 \%)$ \\
& UH & $38(2,9 \%)$ \\
& Politraumatizált CT & $6(0,5 \%)$ \\
\hline Terápia & Nincs & $533(40,2 \%)$ \\
& Infúzió & $711(53,6 \%)$ \\
& Sebellátás + AT & $131(9,9 \%)$ \\
& Szedáció & $139(10,5 \%)$ \\
& Gyógyszerelés & $110(8,2 \%)$ \\
\hline & &
\end{tabular}

AT = ANATOXIN (emlékeztető oltás - tetanusz); CT = számítógépes tomográfia; $\mathrm{RTG}=$ röntgenvizsgálat; $\mathrm{UH}=$ ultrahangvizsgálat

férfiak: 402 fö; 40,9\%). Az igen súlyos befolyásoltságot jelző kategóriában 42 esetben nő, 278 esetben férfi volt a beteg. A nők a „közepes” (33,7\%) és „súlyos” (44,1\%), míg a férfiak a „súlyos” (40,9\%) és „igen súlyos” befolyásoltságot jelző $(28,3 \%)$ kategóriában jelentek meg a leggyakrabban. Az adatokat chi-négyzet-próbával vizsgálva kimutatható volt, hogy van összefüggés a nemek és az alkoholszint befolyásoltságát jelző csoportok között $(\mathrm{p}<0,001)$.

A betegeket életkor szerint 3 csoportba soroltuk. A 18-25 év közötti korosztály átlagos véralkoholszintje $219,62 \pm 80,258 \mathrm{mg} / \mathrm{dl}$ volt, a 26-50 éves korosztálynál ez az érték 296,23 \pm 90,972 mg/dl, az 50 év felettieknél $290,87 \pm 82,461 \mathrm{mg} / \mathrm{dl}$ volt. Összehasonlítva a korcsoportokat, a 18-25 év közöttiek és a 26-50 év közöttiek esetén van összefüggés a korcsoport és a véralkoholszint között $(\mathrm{p}<0,001)$. A 18-25 év közöttieket és az 50 év felettieket összehasonlítva is volt összefüggés a korcsoportok és a véralkoholszint között $(\mathrm{p}<0,001)$. A $25-50$ éves és az 50 év feletti korcsoport esetében azonban nem volt összefüggés a véralkoholszint és korcsoport között $(\mathrm{p}=0,594)$

\section{A diagnosztikai és terápiás eljárások mutatói}

A Sürgősségi Betegellátó Osztályon a betegek számára a legtöbb diagnosztikai eszköz elérhető. Laborvizsgálat minden betegnél történik, amennyiben nem távozik a triage-vizsgálat előtt.

CT-vizsgálat 437 esetben (33\%) történt, ebből 72 esetben $(16,4 \%)$ koponya- és nyakigerinc-CT-vizsgálat 
is. Politrauma-protokoll szerinti CT-vizsgálat 6 esetben $(0,5 \%)$ készült. Röntgenvizsgálat 91 (6,9\%) esetben történt, 6 esetben $(6,5 \%)$ több, mint 1 röntgenvizsgálatra volt szükség. Ultrahangvizsgálatra 38 esetben $(2,9 \%)$ került sor.

533 esetben a beteg nem részesült terápiában, csak kialudta ittasságát, majd távozott. Az esetek 53,6\%-ában, 711 esetben a betegek infúziós terápiában részesültek, folyadékhiány, illetve glükóz pótlása céljából. 139 esetben $(10,5 \%)$ volt szükség a beteg gyógyszeres nyugtatására. A betegek további gyógyszerelésére (hányingercsillapító, fájdalomcsillapító gyógyszer) 110 esetben került sor. Sebellátást 131 esetben kellett végezni, ekkor a beteg tetanuszprofilaxisban is részesült.

\section{A betegek távozásának jellemzôi}

A betegek távozására vonatkozó fóbb adatokat a 4. táblázat mutatja be. A Támasz Alapítvány a téli időszakban gondoskodik a hajléktalan betegek elszállításáról. Ez 80 esetben $(6,0 \%)$ történt meg a vizsgált időszakban. Osztályos felvételre 68 esetben $(5,1 \%)$ került sor. Az osztályos felvételekből $30(44,1 \%)$ esetben szenvedett el a beteg valamilyen sérülést, $38(55,9 \%)$ esetben pedig más volt a probléma. Az osztályos felvételt igénylő betegek körében a következóképpen alakult az alkoholszint befolyásoltságát mutató kategóriák megoszlása: 3 fó $(4,4 \%)$ az „ivott, de nem volt befolyásolt”, I fö $(1,5 \%)$ az ,igen enyhe”, 3 fö $(4,4 \%)$ az „enyhe”, 25 fö $(36,8 \%)$ a „közepes”, 27 fó (39,7\%) a „súlyos”, 9 fo $(13,2 \%)$ az ,igen súlyos" kategóriába tartozott. Az önkényesen, ismeretlen időben, ismeretlen helyre távozottak közül a következőképpen oszlanak meg a számok: „igen enyhe” kategória 4 fo $(1,2 \%), 24$ fo $(7,4 \%)$ az „enyhe” kategóriából, 63 fo (19,5\%) a „közepes”, 133 fo" $(41,2 \%)$ a „súlyos” és 99 fó $(30,7 \%)$ az ,igen súlyos” kategóriából. A távozás módja és az alkoholszint-befolyásoltság között az eredmény szignifikáns összefüggést mutatott $(\mathrm{p}<0,001)$.

\section{Társbetegségek elöfordulása}

Nók esetében 29,5\%-nak volt társbetegsége, míg férfiak esetében 33,4\%-nak. Chi-négyzet-próbával vizsgálva, a nemek és a társbetegségek megléte között nem volt öszszefüggés $(\mathrm{p}=0,207)$.

A leggyakrabban előforduló társbetegségek meglétének gyakoriságát az 5. táblázat mutatja be. A társbetegségek megjelenése a beteg progrediáló állapotára utalhat, így ezen betegek szorosabb megfigyelés alá kerülnek a bejövetelüket követően.

A betegek a sürgősségi osztályon belül is több helyre kerülhetnek, állapotuktól függően. Amennyiben a megfigyelőhelyiségben töltik az idejüket, akkor a fekvőbetegellátásba történő felvételük is megtörténik, így az ellátás végén nemcsak ambulánslapot, hanem zárójelentést is kapnak. A 2016-os év folyamán 13273 esetben került sor fekvőbeteg-elhelyezésre. Vizsgálatunkban 684 eset-
4. táblázat |A betegek távozásával összefüggő adatok

\begin{tabular}{llc}
\hline $\begin{array}{l}\text { A beteg } \\
\text { távozásának helye }\end{array}$ & Haza & $811(61,2 \%)$ \\
& Osztályos felvétel & $68(5,1 \%)$ \\
& Támasz Alapítvány & $80(6,0 \%)$ \\
& Önkényes távozás & $367(27,7 \%)$ \\
\hline A beteg & A triage-vizsgálat előtt & $58(4,4 \%)$ \\
távozásának módja & $\begin{array}{l}\text { A triage-vizsgálat után, de az } \\
\text { orvosi vizsgálat előtt }\end{array}$ & $135(10,2 \%)$ \\
& $\begin{array}{l}\text { Az orvosi vizsgálatok } \\
\text { befejeztével }\end{array}$ & $1133(85,4 \%)$ \\
\hline
\end{tabular}

5. táblázat |A társbetegségek gyakorisága mintánkban

\begin{tabular}{lcc}
\hline Társbetegség & Igen & $431(32,5 \%)$ \\
& Nem & $895(67,5 \%)$ \\
\hline Hypertonia & Igen & $236(17,8 \%)$ \\
& Nem & $1090(82,2 \%)$ \\
\hline Májkárosodás & Igen & $27(2 \%)$ \\
& Nem & $1299(98 \%)$ \\
\hline Stroke & Igen & $12(0,9 \%)$ \\
& Nem & $1314(99,1 \%)$ \\
\hline Görcsrohammal járó rosszullét (élete során) $)$ & Igen & $526(39,6 \%)$ \\
& Nem & $800(60,4 \%)$ \\
\hline Cukorbetegség & Igen & $395(29,7 \%)$ \\
& Nem & $931(70,3 \%)$ \\
\hline
\end{tabular}

ben $(51,6 \%)$ volt a betegnek fekvő megjelenése is, ez a 2016-os évben megjelenők 4,8\%-a. Ezen idő alatt különböző terápiában részesültek a betegek: infúzióban 582 esetben $(85,1 \%), \mathrm{O}_{2}$ adásában 28 esetben $(4,1 \%)$, pluszvérvételben 23 esetben $(3,4 \%)$, vérgázanalízisben 8 esetben $(1,2 \%)$; monitoros megfigyelés 201 esetben $(29,4 \%)$, katéterfelhelyezés 121 esetben (17,7\%) történt.

\section{Betegek megjelenése az év különbözö szakaszaiban}

Az egész év során 1326 eset került vizsgálatra. Ebből 213 eset (16\%) januárban és februárban, 488 (36,81\%) eset pedig szeptember és december között. Ez összesen 701 eset $(52,87 \%)$ volt az őszi-téli időszakban. A március-augusztusi időszakból 625 eset $(47,13 \%)$ került vizsgálatra. A legtöbb beteg decemberben (158 eset; 11,9\%), a legkevesebb pedig júniusban (75 eset; $5,7 \%)$ került felvételre. Vizsgálatunkban a hónapok csoportosítására azért ilyen rendszerben került sor, mert magas a hajléktalan betegek száma, és az ő esetükben az ôszi-téli időszakot figyelembe kell venni, hiszen ekkor sokkal többen érkeznek melegedni az osztályra, mint az év más időszakában. Ez megnövelheti az ittas esetek számát az adott időszakban. Összefüggést vizsgálva a különböző hóna- 
pokban történő megjelenések és a lakhatási körülmények között (rendelkezik-e lakcímmel a beteg vagy sem), az eredmény szignifikáns összefüggést mutatott $(\mathrm{p}=$ $0,022)$.

Vizsgálatunk során összehasonlítottuk a megjelenések számát hétvégi, illetve hétköznapi megjelenések alapján. Hétvégének a szombat 0:00 óra és vasárnap 24:00 óra közötti időszakot tekintettük. Ezek alapján a vizsgált időszakban 492 eset $(37,1 \%)$ történt a hétvégék során, és 834 eset $(62,9 \%)$ a hétköznapokban. Az alkoholszint befolyásoltságra gyakorolt mértéke és a hétvégi megjelenések száma között elmondhatjuk, hogy nem volt összefüggés $(\mathrm{p}=0,437)$.

Az éves megjelenések számát vizsgálva elmondhatjuk, hogy a betegek legtöbbje egy alkalommal jelent meg. Az osztályon a vizsgált időszakban 5 vagy 5 -nél több alkalommal 32 beteg járt. A betegek megjelenéseinek gyakoriságát csoportonként vizsgálva az alábbi képet kapjuk: 5-10 alkalom között: 22 beteg; 10-15 alkalom között: 4 beteg; 16-20 alkalom között: 2 beteg; 21-30 alkalom között: 4 beteg. Ezen betegek összesen 317 alkalommal jártak az osztályon alkoholfogyasztással összefüggésbe hozható felvétel miatt.

\section{A betegek ellátásával kapcsolatos finanszírozási mutatók}

Az alkoholbefolyásoltsággal összefüggésbe hozható esetek a járóbeteg-ellátás után kapott összegnek a 4,9\%-át tette ki. Ez tartalmazza a CT-vizsgálatok után kapott összegeket is.

Vizsgálatunk során fekvőbeteg-finanszírozási elszámolás 683 esetben történt az év során a vizsgált betegcsoportnál. Ez az esetek 51,5\%-át jelentette. Ez a 683 eset az összes fekvőbeteg-bevétel 27,6\%-a volt.

Kiadás szempontjából több összetevőt nem vettünk figyelembe, vizsgálatunk csak a tételesen számolható eszköz-, képalkotó- és gyógyszerigényeket foglalja magában, ez azonban így is számottevő összeg az ellátórendszer részére.

\section{Megbeszélés}

Vizsgálatunk jelentőségét abban látjuk, hogy a detoxikálók megszüntetése után senki nem vizsgálta még, hogy az eddig ott ellátott betegek milyen mértékű terhet jelentenek a sürgősségi osztályok számára, kutatásunk ezért egyedülálló hazánkban. Fontos szempont továbbá, hogy nem csupán egy szemszögből vizsgáltuk meg a helyzetet, hanem az ellátás és a finanszírozás szempontjából is. Minden típusú beteg (belgyógyászati és traumatológiai) beválasztásra került, ami szélesíti a vizsgálati szempontokat.

Vizsgálatunk céljául tűztük ki, hogy felmérjük, milyen arányban fordultak elő az alkoholos befolyásoltsággal érkező betegek a Pécsi Tudományegyetem Klinikai Köz- pontjának Sürgősségi Betegellátó Osztályán a 2016-os évben. Ez az összes beteglétszám 3,3\%-át tette ki, a Sürgősségi Betegellátó Osztályon kezelt többi beteghez képest. WHO-adatok és Vardy és mtsai kutatásában kimutatásra került, hogy az alkoholfogyasztás szignifikánsan összefüggésbe hozható a drogfogyasztással (74,5\%) és az önbántalmazással/túladagolással $(69,5 \%)[3,16]$. A 2016-ban alkoholfogyasztással összefüggésbe hozható halálokok közül az esetek 28\%-ában valamilyen sérülés okozta a beteg halálát (önbántalmazás és egymás közti bántalmazás, közúti baleset) [1]. A diagnosztikai költség, amit ezen betegek ellátására fordítunk, magas, hiszen sok baleset történik, ami az ittasság elkerülésével, megelőzésével nem történne meg, nem lenne szükség a betegek képalkotó vizsgálatára. Más kutatások is kimutatták, hogy az alkohollal összefüggésbe hozható felvételek fó oka valamilyen sérülés bekövetkezte $[9,14,16]$. Egy finn kutatás biciklisek körében vizsgálta az alkoholfogyasztás és a biciklis balesetek összefüggését. Kimutatták, hogy az alkoholt fogyasztó betegek (1629 €) és józanok által elszenvedett balesetek költsége (2173€) különböző, az alacsonyabb az alkoholos befolyásoltság alatt állóké [14].

Vizsgálatunkból kiderült, hogy 58 esetben $(4,4 \%)$ az ittas páciensek már a vizsgálatok megkezdése előtt elhagyták az osztályt, 68 esetben $(5,1 \%)$ pedig intézeti felvételre került sor. Majori és mtsai kutatásában is nagyon magas volt az osztályt a vizsgálatok előtt elhagyók száma (59,3\%). Az ellátottak 4,4\%-a került felvételre valamilyen klinikai osztályra [17]. Dugas és mtsai is említik kutatásukban, hogy ezek a betegek triage során sokszor nem megfelelő módon kerültek osztályozásra, vagy még a vizsgálatok előtt távoztak (49\%) [10].

Elekes a cikkében rámutatott arra, hogy a dolgozó korosztályba tartoznak, akik a mindennapokban több alkoholt fogyasztanak [4]. Ennek több oka is lehet: elsősorban a munkahelyi, családi feszültségek, a stressz kezelése, a baráti összejövetelek gyakorisága, a magány leküzdése. Vizsgálatunkban is ez a korosztály képviseltette magát a leginkább, illetve ezért is határoztuk meg a 'legidősebb' kategória alsó határaként az 50 évet. Ezzel ellentétben egy másik kutatásban a megjelenő betegek $56 \%$-a inaktív volt [10].

$\mathrm{Az}$ alkohollal összefüggésbe hozható betegségek a nők és a férfiak körében nagyon különböző arányt mutatnak (férfiak: 7,4\%, nők: 2,3\%) [3, 9, 11, 18, 19]. Vizsgálatunkban ez a különbség a szakirodalommal megegyező, azonban kutatásunkban nagyobb számban fordulnak elő társbetegségek (férfiak: 33,4\%, nők: 29,5\%) $[3,18,19]$.

A triage-kategóriákat vizsgálva esetünkben a legtöbben a T3-as vagy a T5-ös kategóriába kerültek (T3: 535 eset [40,3\%]; T5: 608 eset [45,9\%]). Ennek oka, hogy azok a betegek, akiknek GCS-értéke 14-15 volt, a vitális paraméterek szempontjából stabil állapotúak, de fejsérülést szenvedtek, T3-as (30 percen belüli orvosi ellátás) kategóriát kaptak, a GCS 14-15, stabil vitális paraméte- 
rekkel (vérnyomás, pulzus, oxigénszaturáció) érkezők, akiknek nincs más problémájuk, csak az ittasság, T5-ös (2 órán belüli orvosi ellátás) kategóriát kaptak. Korábbi kutatásokban is említésre kerülnek a triage-kategóriák, a leggyakoribb a zöld kategória volt $(67,7 \%)$, ami szintén a halasztható kategóriát jelenti ( 2 órán belüli orvosi vizsgálat). Piros ( $\mathrm{Tl}$ - azonnali) kategóriát a betegek 1,9\%-a kapott [17]. Egy másik kutatás csak a Tl-es kategóriában lévő betegeket emelte ki, náluk ennek előfordulása 1,2\% (6 eset) volt [20]. Saját kutatásunkban az esetek 0,6\%-a tartozott a Tl-es kategóriába. Ezek alapján elmondható, hogy az alkoholos állapotban bekerült betegek csak kis százaléka van életveszélyes vagy potenciálisan életveszélyes állapotban, inkább a kisebb sérülések és a biztonságérzetet adó helyen való józanodás miatt kerülnek be az ellátórendszerbe. Több esetben pedig még az előzetes vizsgálat előtt távoznak a betegek $[9,10,12]$.

Vizsgálatunk során a betegek 96\%-ánál készült laborés EKG-vizsgálat, 33\%-uknál CT-vizsgálat. A betegek $53,6 \%$-a részesült infúziós terápiában és 10,5\%-a további gyógyszeres szedációban. Verelst és mtsai kutatásában a betegek 20,3\%-ánál készült EKG-, 12,3\%-ánál koponyaCT-vizsgálat, a betegek $67,7 \%$-a részesült infúziós terápiában, 47,9\%-a $\mathrm{B}_{1}$-vitamint, 43,6\%-a benzodiazepint kapott [20].

\section{A kutatás korlátai}

Kutatásunk korlátait jelenti, hogy a kutatás során csak egy klinikai központ sürgősségi osztályát vizsgáltuk meg, így nem reprezentatív a teljes hazai ellátórendszerre. Továbbá az adatok szúrése BNO-kódok alapján történt, a kódolást az ellátó orvos vagy az adminisztrátor végzi. Ez azt jelenti, hogy amennyiben az orvos vagy az adminisztrátor nem kódolja be az esethez az alkoholos befolyásoltság szintjeihez tartozó kódokat, úgy vannak esetek, amelyek kimaradhattak a vizsgálatból.

A bevételek vizsgálatánál az esetek elszámolási nyilatkozatait vettük alapul, illetve az OENO-kódok meghatározásával használt forintértékeket [21].

A kiadások vizsgálatánál csak a valóban tételesen számolható összeget vettük figyelembe. Ennek oka, hogy nagyon nehéz meghatározni az adott múszakban megjelenő, alkoholos befolyásoltság alatt álló betegre szánt munkaidőt a kollégák részéről, illetve az infrastrukturális kiadások pontos megítélése is nehézséget okoz.

\section{Következtetés}

Vizsgálatunk mintája a szociodemográfiai jellemzőiben hasonló a nemzetközi szakirodalomban megjelentekhez, azonban a hazai kutatásoktól eltér, a nemenkénti megoszlás és a korcsoportok tekintetében is. Ennek okaként az eltérő vizsgálati helyszínt (háziorvosi rendelő és Sürgősségi Betegellátó Osztály), valamint a vizsgált alkoholfogyasztási eseteket (a krónikus alkoholfogyasztáshoz társuló megbetegedések miatt orvost felkereső és akut intoxikáció miatt kórházba kerülő) gondoljuk. Vizsgálatunkban a sérülések diagnosztikája és ellátása, valamint a betegek detoxikálása is a hazai és klinikai központi szintú irányelveknek megfelelően történt.

Finanszírozási szempontból kijelenthetjük, hogy a várttal ellentétben ezen betegek ellátása nyereséges az osztály számára, bár a kiadások szempontjából csak a fix költségek kerültek összegzésre. A változó kiadások vizsgálatát is számba véve ezen eredmények változhatnak.

Kutatásunk eredményei alapján elmondható, hogy az SBO-n az akut alkoholintoxikációval megjelenő betegek aránya nem magas a többi betegéhez képest, azonban ezen betegek több mint fele kizárólag az alkoholfogyasztás miatt kerül felvételre detoxikálás céljából. Az alkoholfogyasztással összefüggésbe hozható sérülések miatt megjelenők száma ebben a betegcsoportban magas, azonban az alkoholfogyasztással összefüggésbe hozható más betegségek aránya elenyésző.

Anyagi támogatás: Jelen kutatás és a közlemény megírása anyagi támogatásban nem részesült.

Szerzői munkamegosztás: B.-Cs. H.: A kézirat koncepciójának kialakítása, a szakirodalmi áttekintés elvégzése, a dokumentációk elemzése, adatok gyüjtése, a statisztikai elemzés elvégzése, a kézirat megírása, a magyar és angol nyelvű összefoglaló elkészítése. B. B.: Részvétel szakirodalmi adatok gyưjtésében, adatgyưjitésben, a kézirat végleges formájának áttekintése. B. I.: Részvétel a kutatás lefolytatásában, a gazdasági elemzés áttekintése, javaslatok megfogalmazása. B. J.: A kézirat végleges formájának kritikus tanulmányozása, javaslatok megfogalmazása, ezek alapján a munka korrigálása. A cikk végleges változatát valamennyi szerző elolvasta és jóváhagyta.

Érdekeltségek: A szerzőknek nincsenek érdekeltségeik.

\section{Irodalom}

[1] WHO. Harmful use of alcohol kills more than 3 million people each year, most of them men. World Health Organization, Geneva, 2018. Available from: https://www.who.int/news-room/ detail/21-09-2018-harmful-use-of-alcohol-kills-more-than3-million-people-each-year-most-of-them-men [accessed: May 13, 2019].

[2] Bede A. Alcoholic patients in primary care. [Alkoholbetegek az alapellátásban.] Magy Csalorv L. 2012; 6: 15-16. [Hungarian]

[3] WHO. Global status report on alcohol and health. World Health Organization, Geneva, 2014. Available from: http://www.who. int/substance_abuse/publications/global_alcohol_report/ msb_gsr_2014_1.pdf?ua=1 [accessed: December 4, 2018].

[4] Elekes Zs. Alcohol problem among primary health care patients. [Alkoholprobléma a háziorvosi rendelők betegei között.] Demográfia 2015; 58: 145-171. [Hungarian]

[5] European population health survey, 2014. [Európai lakossági egészségfelmérés, 2014.] Statisztikai Tükör 2015; 29: 1-9. Available from: https://www.ksh.hu/docs/hun/xftp/stattukor/elef14.pdf [accessed: December 4, 2018].

[6] Barbieri S, Feltracco P, Lucchetta V, et al. A social media-based acute alcohol consumption behaviour (neknomination): case 
series in Italian emergency departments. Interact J Med Res. 2018; 7: e2

[7] Du Y, Wolf IK, Knopf H. Psychotropic drug use and alcohol consumption among older adults in Germany: results of the German Health Interview and Examination Survey for Adults 20082011. BMJ Open 2016; 6: e012182.

[8] Betlehem J, Radnai B. The place of Model of Emergency Academy in the improvement of health promotion. [A Sürgôsségi Akadémia Modell helye az egészségügyi ellátás fejlesztésében.] Egészség Akadémia 2012; 3: 7-15. [Hungarian]

[9] Parkinson K, Newbury-Brich D, Phillipson A, et al. Prevalence of alcohol related attendance at an inner city emergency department and its impact: a dual prospective and retrospective cohort study. Emerg Med J. 2016; 33: 187-193.

[10] Dugas S, Favrod-Coune T, Poletti PA, et al. Pitfalls in the triage and evaluation of patients with suspected acute ethanol intoxication in an emergency department. Intern Emerg Med. 2019; 14: $467-473$.

[11] Comelli I, Lippi G, Sanchis-Gomar F, et al. Visits for alcoholrelated problems in a large urban emergency department. Results of a 15-year survey. Acta Biomed. 2018; 88: 514-518.

[12] Cole JB, Klein LR, Martel ML. Parenteral antipsychotic choice and its association with emergency department length of stay for acute agitation secondary to alcohol intoxication. Acad Emerg Med. 2019; 26: 79-84.

[13] Rehm J, Mathers C, Popova S, et al. Global burden of disease and injury and economic cost attributable to alcohol use and alcohol-use disorders. Lancet 2009; 373: 2223-2233.

[14] Airaksinen NK, Nurmi-Lüthje IS, Kataja JM, et al. Cycling injuries and alcohol. Injury 2018; 49: 945-952.
[15] http://semmelweis.hu/igazsagugy/files/2012/06/13_mszlev. pdf [Hungarian]

[16] Vardy J, Keliher T, Fisher J, et al. Quantifying alcohol-related emergency admissions is a UK tertiary referral hospital: a crosssectional study of chronic alcohol dependency and acute alcohol intoxication. BMJ Open 2016; 6: e010005.

[17] Majori S, Ricci G, Marchiori F, et al. Prevalence of acute alcohol intoxication in Borgo Trento Hospital Emergency Department (Verona). J Prev Med Hyg. 2015; 56: E196-E202.

[18] Martin N, Newbury-Birch D, Duckett J, et al. A retrospective analysis of the nature, extent and cost of alcohol-related emergency calls to the ambulance service in an English region. Alcohol Alcohol. 2012; 47: 191-197.

[19] Lin HL, Lin TY, Soo KM, et al. The effect of alcohol intoxication on mortality of blunt head injury. Biomed Res Int. 2014; 2014: 619231

[20] Verelst S, Moonen PJ, Desruelles D, et al. Emergency department visits due to alcohol intoxication: characteristics of patients and impact on the emergency room. Alcohol Alcohol. 2012; 47: 433-438.

[21] finanszirozas.oep.hu/raford/szakkoll/OENO_kompetencia_2008_07_02.xls [Hungarian]

(Bánfai-Csonka Henrietta, Pécs, Vörösmarty u. 4., 7621 e-mail: csonka.henrietta@pte.hu)

\section{"Audax est ad poculum sermo." (Gyakran lesz szabadabb szájú poharazva az ember.)}

A cikk a Creative Commons Attribution 4.0 International License (https://creativecommons.org/licenses/by/4.0/) feltételei szerint publikált Open Access közlemény, melynek szellemében a cikk bármilyen médiumban szabadon felhasználható, megosztható és újraközölhetö, feltéve, hogy az eredeti szerző és a közlés helye, illetve a CC License linkje és az esetlegesen végrehajtott módosítások feltüntetésre kerülnek. (SID_1) 